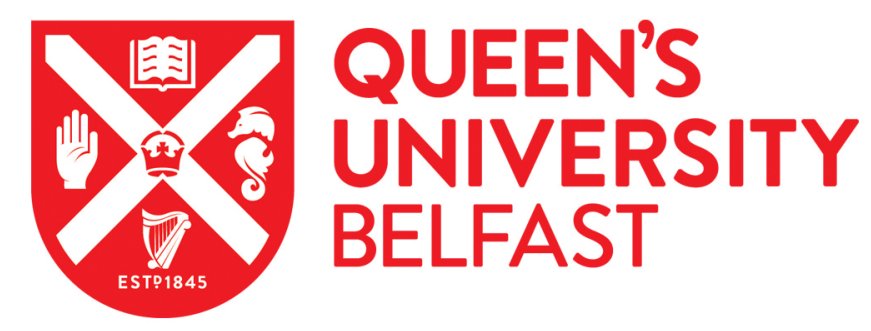

\title{
The Letterbox Club book gifting intervention. Findings from a qualitative evaluation accompanying a randomised controlled trial
}

Roberts, J., Winter, K., \& Connolly, P. (2017). The Letterbox Club book gifting intervention. Findings from a qualitative evaluation accompanying a randomised controlled trial. Children and Youth Services Review, 73, 467-473. https://doi.org/10.1016/j.childyouth.2016.11.016

Published in:

Children and Youth Services Review

Document Version:

Peer reviewed version

Queen's University Belfast - Research Portal:

Link to publication record in Queen's University Belfast Research Portal

Publisher rights

(C) 2016 Elsevier Ltd. All rights reserved. This manuscript version is made available under the CC-BY-NC-ND 4.0 license

http://creativecommons.org/licenses/by-nc-nd/4.0/which permits distribution and reproduction for non-commercial purposes, provided the author and source are cited.

\section{General rights}

Copyright for the publications made accessible via the Queen's University Belfast Research Portal is retained by the author(s) and / or other copyright owners and it is a condition of accessing these publications that users recognise and abide by the legal requirements associated with these rights.

Take down policy

The Research Portal is Queen's institutional repository that provides access to Queen's research output. Every effort has been made to ensure that content in the Research Portal does not infringe any person's rights, or applicable UK laws. If you discover content in the Research Portal that you believe breaches copyright or violates any law, please contact openaccess@qub.ac.uk. 


\section{The Letterbox Club book gifting intervention for children in foster}

care: how it works and how it could work better

\section{Abstract}

It is now widely accepted that reporting the results of randomised controlled trials should encompass a complimentary focus on both outcome measures and process measures. Reflective of the current thinking, this article reports on the findings from a qualitative evaluation that accompanied a randomised controlled trial of the Letterbox Club; a book gifting intervention for children in foster care. Outcome measures used in the trial have recently been reported on (Mooney, Winter, \& Connolly, 2016). Findings showed no significant effects in terms of improvements to children's literacy skills and/or enjoyment of reading. Through in-depth interviews with 20 foster children, their carers and the programme developer, the qualitative evaluation focused on how and why the intervention did not achieve greater impact. Findings illustrate differences between the 'hoped for' outcomes of the intervention, and carer/child levels of engagement with and experiences of the programme. In order to move the programme forward and begin to explore the findings, a logic model is suggested which accounts for the current findings regarding the use and lived experiences which carers had with the packs. Wider implications for the conduct of these types of randomised controlled trials are discussed. 
Key words: Book gifting; RCT; process evaluation; theory of change; logic model; children in out of home care.

\section{Background}

It is now widely accepted that reporting the results of randomised controlled trials should encompass a complimentary focus on both outcome measures and process measures (Moore, Audrey, Barker, Bond, Bonell, Hardeman, Moore, O'Cathain, Tinati, Wight, \& Baird, 2015). In social work research in the U.K this is a relatively new area because, although there are studies using this methodological approach, randomized controlled trials are still relatively rare (Dixon, Biehal, Green, Sinclair, Kay, \& Parry, 2014; Mezey, Robinson, Campbell, Gillard, Macdonald, Meyer, Bonell, \& White, 2015; Thyer, 2015). Common assumptions are that they are 'an impractical, inappropriate, unethical, and rarely undertaken research method for use in social work' (Thyer, 2015, p. 753). On a practical level RCT's can be costly and risky to undertake - resource intensive and with a strong possibility that the findings will be diluted given difficulties with participant recruitment, random allocation and retention (Dixon et al., 2014; Mezey et al., 2015). Ethically it is argued that the random allocation of children or carers to the intervention or control group, and so denies those in the control group access to a service at the point of need is incompatible with social work values and principles. Even with a waiting list design the children or carers, while getting the service, still have to wait. Another argument is that a focus on measurable outcomes results in other benefits that are 
difficult or impossible to measure being missed. The associated fear here is that, as part of the government's wider emphasis on the importance of evidence based interventions, services where the focus is on processes and not outcomes are vulnerable.

In challenging some of these assumptions, Thyer (2015, p. 757) in a recently published bibliography of randomised controlled trial experiments in social work, has located over 740 studies stretching back over at least 60 years on an 'amazing variety of research topics [that represent] a plethora of problems, interpersonal, psychological, psychosocial, and community-based issues [and where] independent variables included psychosocial interventions, biological therapies, educational methods, and social welfare and policies'. Three main points stem from this bibliography - RCT's do exist in social work, they can be undertaken in an ethical manner and an experimental design is an appropriate social work research method for addressing questions of effectiveness, impact and outcomes. The randomised controlled trial of the Letterbox Club (Mooney et al., 2016) makes a significant contribution to these debates concerning as it does, the effectiveness of a reading intervention for young children, aged 7-11 years old, in foster care. As such it is one of the first RCT's in the UK to be conducted with this vulnerable group of children and the first RCT to be undertaken with the Letterbox Club. While the results of the trial show that it was not effective in relation to the measures selected, these results are only partial in that they do not tell us why this might be the case. Hence the focus of this paper is on process measures that will, 
in turn, help make sense of findings from the outcome measures Moore et al., 2015). The difference between the two is simple - outcome measures focus on answering the question 'Is this intervention effective or not?'; whereas process measures address the questions 'How, why and in what circumstances is this intervention effective or not'.

\section{The Letterbox Club and theory of change}

In the UK, The Letterbox Club is the most well-known, popular and well regarded book gifting intervention for children in foster care ages 513 years (http://www.letterboxclub.org.uk). In England and Wales children are enrolled through participating Local Authorities and in Northern Ireland all children in foster care automatically become members of the scheme which involves the delivery of personalised colourful packs to children in their foster home once monthly for 6 months of the year (May-October inclusive). The time period coincides with the summer recess and the summer dip in children's literacy and numeracy skills (McCombs et al. (2011). Packs contain books, stationery, a letter explaining the content and maths activities.

A number of evaluations have been undertaken (see overview in Mooney et al., 2016), mainly by the programme developers (Griffiths, 2012; Dymoke, \& Griffiths, 2010; Griffiths, Comber, \& Dymoke, 2010). These have indicated very positive findings in terms of attainment scores and children's like of the packs. Studies by others, for example Hancock 
and Leslie (2014), which consisted primarily of in-depth case studies, found that although some children did enjoy the parcels, not all did. It was noted that:

throughout the pilot all the children and carers reflected on the benefits of receiving the parcels. However, a few of the participants also highlighted challenges such as the demands of the reading materials, the time constraints [and that] some of the resources in the parcels were not at an appropriate level for their stage of development' (Hancock and Leslie, 2014, p.46).

These most recent, albeit small scale, qualitative findings appear to indicate that that there may be some issues connected with the design and delivery of the programme, in particular its aims and objectives compared with its lived experience, that require further consideration. Whilst these past studies have examined the processes which children go through when they receive The Letterbox Club, they fail to ascertain what changes are occurring and the reasons behind why children feel this way. The study, its design, ethics and methods are explored next before going on to present the findings under each of the four themes identified.

\section{The current study: design, ethics and methods}

Through the use of a randomised controlled study with a waiting list design, the research sought to measure the effectiveness of a book gifting intervention known as "The Letterbox Club'. Using standardised measures, the Neale Reading Analysis of Reading Ability (Neale, 1989; 
1997) and the Elementary Reading Attitude Survey (McKenna and Kear, 1990), 116 foster children ages 7-11 years old were involved in the study that took place in Northern Ireland between 2013 and 2014. All aspects of the trial and its findings are reported elsewhere (Mooney et al., 2016).

While the trial itself had involved all children in foster care across the five Health and Social Care Trusts in Northern Ireland, the process evaluation involved interviews with children and their foster carers in one of the five Trust areas chosen for a number of reasons. Geographically, this is the largest of the trust areas in Northern Ireland. It has a wide mix of children in a range of circumstances, including kinship, foster care, children with special needs and children from rural and urban locations. This Trust area was also the most consistent in terms of fieldworkers with carers and children getting to know the research team well. Choosing this Trust area also made sense for ethical reasons, as this trust were the most able to grant ethical consent within the timescales. Ideally this sample would have been larger, however this was not the case given time and capacity constraints.

Ethical approval was gained from the university, the Trust and the regional ethics body for Northern Ireland ORECNI. Verbal consent was secured from the participants involved over the phone, since they had already given written consent to be involved in the study overall. Once each carer had been contacted and verbal permission received, a date for the interview to take place was decided upon. This was followed up with a phone call to remind them of the appointment the day before it was due. 
The interviews with foster children and their carers took place at the foster carers' homes. In total Interviews took place with 20 children and 11 foster carers and typically involved the child and the foster carer. An overview of the sample is included in Table One below. One interview took place with the programme developer.

Table One: Qualitative Interview Sample

\begin{tabular}{|l|l|l|l|l|l|l|}
\hline $\begin{array}{l}\text { Age } \\
\text { of } \\
\text { child }\end{array}$ & Group & Gender & $\begin{array}{l}\text { Placement } \\
\text { type }\end{array}$ & $\begin{array}{l}\text { Interview } \\
\text { location }\end{array}$ & $\begin{array}{l}\text { Carer } \\
\text { interview }\end{array}$ & Recorded \\
\hline P4 & I & Male & Foster & Living Room & Yes & Sound \\
\hline P4 & I & Male & Kinship & Kitchen & Yes & Sound \\
\hline P6 & C & Female & Foster & Living Room & Yes & Sound \\
\hline P4 & I & Female & Foster & Living Room & Yes & Sound \\
\hline P4 & C & Female & Foster & Living Room & Yes & Sound \\
\hline P6 & C & Female & Foster & Kitchen & Yes & Sound \\
\hline P6 & I & Male & Foster & Conservatory & Yes & Sound \\
\hline P4 & I & Female & Foster & Living Room & Yes & Sound \\
\hline P6 & C & Male & Foster & 'Good Room' & Yes & Sound \\
\hline P6 & C & Female & Kinship & Living Room & No & Sound \\
\hline P4 & C & Female & Foster & Living Room & No & Sound \\
\hline P4 & C & Female & Foster & Kitchen & No & Sound \\
\hline P4 & I & Male & Foster & Study & No & Sound \\
\hline P4 & I & Female & Foster & Office & Yes & Sound \\
\hline
\end{tabular}




\begin{tabular}{|l|l|l|l|l|l|l|}
\hline P6 & C & Female & Foster & Conservatory & No & Sound \\
\hline P6 & I & Female & Kinship & Living room & No & Sound \\
\hline P6 & C & Male & Foster & Kitchen & No & Sound \\
\hline P4 & C & Male & Foster & Kitchen & No & Sound \\
\hline P6 & I & Male & Foster & Living Room & Yes & Sound \\
\hline
\end{tabular}

\section{The interviews}

The carers' interview schedule consisted of a series of questions which aimed to look at the use of the parcels in the house and the general literacy environment. Here, levels of support provided to the children in care regarding reading and education in general were examined and discussions were prompted regarding the broader literacy environment in the home. Questions regarding the training and support they had received or felt they would need were also included in order to assess how carers felt they could best support the children they were working with. The child's interview schedule aimed to assess the child's level of engagement with the programme and tried to follow their use and engagement with the parcels from the time of receipt. Children were also asked questions about the content of the parcels and the support they had received in the home when working with the parcels. The interview schedule used with the programme creator was designed to trace the ideas around the programme and the theory behind its design. Whilst these interview schedules provided a springboard for discussions, the interviews were semi-structured, and so discussions based upon their responses were 
also developed in order to begin to develop a full picture of the programme. For the most part open ended questions were used, as these allow opinions to be expressed more fully.

Each interview typically lasted around 30 minutes. With permission, interviews were recorded using a smart pen, which recorded audio data and written data. The vast majority of the children were completely at ease being recorded; however, some did ask questions about the pen. These children were allowed to play with the pen prior to the interview and were encouraged to listen back to themselves to put them at ease. Data was transferred from the recording pen after each interview and transcribed with the longest interviews purposively being transcribed first to facilitate the development of a good overview of the multiplicity of emergent themes before transcribing the remainder of the interviews in a chronological order.

Manual methods were used to conduct a thematic analysis of the interviews, as this can prove the most thorough when dealing with interviews of this type. Once all the interviews had been transcribed a thematic analysis approach to the analysis was undertaken (Braun and Clarke, 2006) in which initial codes were derived from reading the lengthiest transcripts and then following a process of initial coding, codes and themes were refined. Due to this process of generating themes and the small sample size, it is noted that findings presented here may not be 
fully generalizable, however these findings are important to the programme as a whole and allow carer and child voice to come through. Findings are considered under the themes of ownership; attitude; engagement; and ability.

\section{Ownership}

Dymoke and Griffiths (2010, p. 53) state that 'ownership of texts, both in the literal and in the metaphorical sense, is a significant element in the process of becoming and perceiving oneself as a reader'. In operationalising the concept of 'ownership', or, in this case, how the books might create a sense of ownership, the term appears, from the written material, to comprise a number of components: being present when the books arrive at the home; emotions at the time of arrival and opening of the parcels; and a place to store and access the books. In terms of the arrival of the parcels, our research revealed that most children were in school when the parcels came, as one child stated 'they brought them to the post office and my Nanny had to go and collect them' (Ruby), whilst another says '(carer) got it, and then when I came in it was there for me and I could go over and get it' (Tom). These were fairly typical responses, with most of the children reporting the carers taking the parcel and leaving it for them to get at a later time, normally after school. However, where children were at home when the parcel arrived this created feelings of happiness and expectation: 
Ian: I love getting mail

Researcher: If you were at home what did you do?

Ian: I got it straight away because I love getting mail

Researcher: Oh do you?

Ian: Yes- I always look to see if there's something for me in there

On further exploration, our research revealed that a number of factors might contribute to feelings of excitement as indicated below:

Researcher: Why do you think that you love getting mail?

Ian: Because of the excitement that there might be something special for me, like a letter from my mummy or something. Although how she would get our address I don't know, I don't randomly go around giving my address to people or something.

This example alludes to the important role of the carer in explaining what the parcels are, where they come from, who they come from, how the address has been obtained and provision of reassurance that that there are 'no strings attached' to the receipt of the free gift. Rather than the sense of ownership spontaneously arising on receipt of a parcel in the post, our research indicated that the emergence and growth of feelings of ownership was more a process over time, growing if sufficiently nurtured by the adult carers. Hence, where carers: showed an active interest in the arrival of the parcel and its contents and encouraged children to choose the best storage space these actions appeared to strengthen, support and 
legitimize the child's sense of ownership. Particular examples included children keeping materials in a designated bookcase or cupboard either in their bedrooms or in a central location, typically with other books, for the whole house to use and enjoy.

On the other hand, where these supportive activities around the arrival of the books appear to have been less pronounced or did not take place (often through lack of time and competing demands) some children put the contents back into the envelope after each use and three of the children specifically stated that they kept the books in the envelopes all of the time. When asked why one child expressed worried about the perceived repercussions if they lost the parcel and another that they were not sure if the parcel was a gift or a loan. We also heard from children who handed to friends, neighbours and other family members, books from their parcels and who had not formed a sense of ownership. In exploring this it is clear that sense of ownership is inextricably linked to a child's understanding about the parcels and the carers own levels of support to the child in nurturing their sense of ownership.

\section{Attitude}

Some children had a positive attitude towards the parcels, were delighted to receive a free gift and took this on face value accepting it for what it was - a free gift to them, for them and to be used by them. Other children had a less positive attitude. Some appeared embarrassed at 
receiving a parcel, especially where there were birth children of similar ages in the home who had obviously not received a free gift; children who were guarded in their responses to the free gift thinking that it came with strings attached or hidden messages from home; and children who were indifferent either because they had enough books at home, or preferred to engage with forms of reading including computers, IPads and or kindles.

The implicit assumptions behind the parcels, that children will be grateful at receiving the book gift; and that they are (book) deprived, hungry to read, grateful and ready to learn; were not always evident in the accounts of the children. In fact, it was found that, in reality, some children were not comfortable receiving free gifts and that others were book burdened'. Some foster children had a wide variety of materials and a lack of time for reading. Furthermore, as noted in the research of children may not be hungry to read or ready to read, but rather lack the affective components which provide the antecedents to reading development, such as confidence and motivation (Hedin, Höjer \& Brunnberg, 2011; Cheung, Lwin \& Jenkins, 2012). Indeed, children may not be 'ready to learn' due to their past experiences, serious health issues and emotional, social and behavioural difficulties. Again, the role of the carer in shaping, supporting and sustaining children's positive attitudes was highlighted as a significant factor.

\section{Engagement}


In this research when the term 'engagement' was operationalised, it was clear that this was a combination of having a sense of ownership and a positive attitude both of which are processes rather than one off responses and both of which are supported and nurtured by adult carers and a receptive social context. It is not surprising that given wide variation in the sense of ownership and attitudes held by children towards the parcels that their levels of engagement also varied. This research found that children's reasons for engaging with the parcels, their motivation is closely aligned to their understanding from their carers as to what the parcels are for, where they come from, who sent them and why - that is children benefit from hearing about and being reassured about the motivations of the sender. This is important because we know that some children in care have been exposed to the malevolent intentions of adults who have used gifts as part of a grooming process (Bennett and O' Donohue, 2014).

A child's motivation to engage is also affected by more practical considerations such as parcel content. Importantly $\mathrm{Dr}$ Griffiths, the programme creator stated in our interview with her that the packs were not designed to please ' $100 \%$ of the children $100 \%$ of the time', rather there were books which were selected to appeal to a wide variety of children and which would help open children to new genres and new styles of writing. In reality, some children were left unimpressed with the choice of books. Almost all children had some books that they did not like. Similarly, some of the children had already read the books, and so were 
left with duplicates. For example, one child stated that 'I had already read that one' (Ruby), another said that 'I didn't like Chitty Chitty Bang Bang Flies Again' (Patricia).

Interestingly Chitty Chitty Bang Bang Flies Again proved to be the most controversial choice included in the parcels, mainly due to its ending, that concludes with a cliff-hanger, where we are led to believe that a sequel will take place. Some children could appreciate this from a literary perspective. However, for some, they felt that this was less than ideal, one child stated that 'it just ended, in the middle and it was so annoying! (Ruby)'. Children were also able to pick out and identify books which they did enjoy and which they found inspiring, for example:

I liked The Finger Eater because it was scary (Helen).

In addition to mixed feelings about individual books there were a number of different responses to the level of texts provided. Some felt that the packs were:

Too 'babyish'- 'umm I liked the... not like the reading books... but like the not reading books and like the other stuff I got. The reading books were too babyish (Jill).

In this example, the books were not read or used to their full potential because the child in question, who was an avid reader and who was very keen and able, felt that the books did not match either her ability level or her interest level. In this case the books were kept upstairs, or 'in a cupboard somewhere'. Others felt the books were too hard. This finding 
is in line with research findings, which show that 'interest is associated with persistence and achievement', (Clark and Phythian-Sence, 2008, p.3) and so books which appeal to both an interest level and a readability level are crucial for motivation, engagement and improvements in reading (Ryan and Deci, 2000; Guthrie and Davis, 2003).

Hence it appears from our research and that of others (Handley, 2013) that three elements are important in supporting children's engagement in the books: first being supported to develop a sense of ownership; second, getting books they like; and third, promoting their choice over reading materials. With regard to the Letterbox Club, one of the things that the programme implementers try to do is to include books which are aimed at the interest level of the child, however children do not have the same interest level, and that without the child's own input it appears increasingly difficult to decide what an individual will find interesting, irrespective of age or ability. Engagement also appears affected by a clear understanding of what to do with the parcel contents. This applies particularly to the stationery items and numeracy materials. In relation to the stationery items, most of the children reported enjoying them and using them in a variety of ways. Blank notebooks were popular with some children as they could do what they wanted with them. One child enthusiastically stated 'I LOVED them books!' (Nicola). Others said:

Me and (carer) uses them...for birthday cards and birthdays' (Oliver), 
'I used the blank books for like, I used it to write- right now I'm using it to write, because me and my cousin we made up a dance' (Ruby). However, other children reported not knowing what to do with the blank notebooks. One child said:

I didn't know what actually I had to do,' (Mark), '

And another:

Well...what were, you know, them jotter books actually for?' (Lisa)

Furthermore, the following extract with both a carer and child shows that, in this family, there was an abundance of stationery materials, which were seen as useful, hoarded and kept rather than given any real use by the child. In contrast, the carer took the view that the materials were not helpful for the child:

Researcher: And did you use the blank books and stationery?

Debbie: Yeah

Dawn: I just felt there was a surplus, and even the pencils and things, you would have lots of drawing things, we have a drawer full of pencils so you didn't need them

Debbie: Yeah but we needed the rubbers, we only had hardly any rubbers mum, sure they were all ripped and everything

Dawn: I could say I could look at your pencil case and there is loads, I could put my hand on half a dozen rubbers. 
Children's engagement with the maths games also varied. There were some positive experiences:

Ruby: I liked the one where one person had a calculator and the other person had to try to add it up in their head as close as they could get it

Helen: I loved bingo so I did, it was great!

Kelly: Snakes and ladders, I liked that one

On the other hand, the following interview excerpt shows the feelings of one child who felt unable to engage with some of the maths games:

Researcher: What about the maths games?

Ian: I didn't really play those

Researcher: Why not?

Ian: Sometimes I don't really have time to play them and sometimes I don't really have anyone to play them with

Researcher: did you look at them before you decided?

Ian: I looked at them before I decided- I don't just completely brush off

Researcher: so you looked and decided they weren't for you. Where did you put them?

Ian: I just put them back in the thing 
Researcher: and do you still have them or did you give them to someone else?

Ian: they are still somewhere but no one else would really want them.

It can be seen, as highlighted earlier, that levels of engagement are inextricably connected with the role of the carer. Here, below, the carer explains their approach to the stationery items:

Researcher: Now inside the parcels there was also blank books and stationery items inside - did you use any of them?

Kelly: No, none of them

Researcher: And why didn't you use those?

Kelly: I don't know

Kate (Carer): Because I don't allow any pens in the house because they always just write on the walls.

Carer attitude towards and engagement with the parcels therefore had an impact on the levels and type of child engagement with the parcels. It was reported in our research that, in relation to the parcel contents, these were either kept 'just in case', in the hope they 'might play them one day' or given to a charity shop (this was the case for two children), kept in a different location (this was the case for two children) and/or lost. 


\section{Ability}

The findings of the RCT indicate that there were no statistically significant gains in relation to any of the outcome measures used namely: reading accuracy, rate and comprehension; reading enjoyment; and recreational reading. The qualitative findings help begin to explore why this might be the case. Four main points are important to highlight. First, children have expressed the view that they want to be more actively engaged in the book gifting process. Second, at its core, this scheme positions the child as 'hungry to read', yet there is little evidence to back that assumption. For many children reading was bolted on to lots of other events. Third, for those who did read, they used a range of modalities, including E-Readers, tablet computers and magazines. Interestingly, a survey by Holloway, Green, \& Livingstone (2013) found that tablet use at home by children aged 5 to 15 rose from $14 \%$ to $42 \%$ in just one year, from 2012 to 2013. Picton (2014) also found that children were more likely to read on screen outside of school and that they preferred to read on screen (52.4\%) rather than read in print (32\%).

Fourth, the current focus of the programme is on the individual child and presupposes that the child's receipt of a gift alone will encourage ownership, promote a positive attitude, increase engagement and improve ability. However, findings from the qualitative study, illustrate that child factors (likes, dislikes; preferences; background factors; foster family context) and contextual factors (in particular the crucial role of adults in creating spaces, opportunities and supports for children to exercise their 
evolving capacities in relation to reading) impinge on the entire engagement process. Together these factors seem to suggest that it is important to use these findings in order to develop a theory of change which can help explain the programme, and translate this to a workable logic model which lays out the actual programme components).

\section{The theory of change}

When beginning to examine how a proposed programme will work it is important to develop a theory of change. This allows everyone involved to see clearly what links are being made and how these will lead to the proposed changes. Drawing from the qualitative evidence, it becomes clear that in this intervention, both child factors and adult factors need to be taken into account. We suggest that a combination of the following two frameworks provide a useful start point: first, the principle of the evolving capacities of the child as defined in the United Nations Convention on the Rights of the Child (UN, 1989); and second the framework for supporting the application of evolving capacities which is based upon the work of Vygotsky (1978) and specifically his concepts of the zone of proximal development and scaffolding.

Evolving capacities is a term used in the United Nations Convention on the Rights of the Child (UN, 1989), a human rights treaty, that sets out the civil, political, economic, educational, social, health related and cultural rights of children. The importance of the Convention is that it makes clear the right of every child to an education (articles 28 and 29) and that in 
engaging with this and other rights, the direction and guidance to the child, provided by parents or others with responsibility for the child, must take into account the evolving capacities of the child to exercise their rights on his or her own behalf. While evolving capacities has a Piagetian age/stage developmental dimension - with age comes an increased ability to engage with and exercise rights - the concept also recognises the impact of a child's environment and clearly points to the responsibilities of adults within it to provide children with support and opportunities commensurate with the child's evolving capacities.

Vygotsky and the concepts of zone of proximal development (ZPD) and scaffolding provide a useful framework for applying the principle of evolving capacities. Vygotsky defines the ZPD as:

the distance between the actual developmental level as determined by independent problem solving and the level of potential development as determined through problem solving under adult guidance, or in collaboration with more capable peers (Vygotsky, 1978, p. 86).

Vygotsky (1978, p. 87) goes on to explain 'there are two groups of functions; those the children already possess and those they can perform under guidance, in groups, and in collaboration with each other but which they have not mastered independently'. Of particular resonance to the foster children who receive the book gifting programme Letterbox club is the following observation by Vygotsky (1978, p. 90): 
an essential feature of learning is that it creates the ZPD; that is learning awakens a variety of internal developmental processes that are able to operate only when the child is interacting with people in his environment and in cooperation with his peers. Once these processes are internalized, they become part of the child's independent developmental achievement'.

Where adults are positioned by virtue of their experience, age, status, experience, expertise as 'the more knowledgeable other' they can support and create opportunities to assist the child to reach forward and this process is known as scaffolding. A range of activities could be described as scaffolding. The role of the adult therefore is a key mechanism explaining why we might expect that a child's receipt of a book gifting programme might lead to improved literacy scores.

\section{A logic model and implications}

Whilst this assumption rings true, this analysis suggests that the component parts of effective carer support are not clearly defined and that some carers maybe unaware how and when to help foster children in their care. In order to map out an effective plan which focuses on the links and processes upon which this type of intervention relies, a logic model is necessary. A logic model is a way of presenting a plausible and sensible method as to how a programme will work under certain conditions to solve identified problems and is fundamental to programme evaluation (Bickman, 1987; Dwyer \& Makin, 1997; Millar, Simeone \& Carnevale, 
2001; Bucher, 2010). They typically consist of several variables, normally including inputs, outputs and processes (Hens, Kriz and Wolfe (2009). Indeed, one of the major features of a logic model is its ability to communicate in a concise manner the entire course of a programme from implementation to its end (Bellini, Henry and Pratt, 2011, p 40). Logic models highlight how an intervention is supposed to work in theory, map out the processes involved in interventions; and can act as a clear visual representation of the changes involved in the learning processes.

Creating a logic model at the beginning of a programme allows for the aims and objectives to become explicit to all be involved from the outset (Page, Parker and Renger, 2009).

In relation to The Letterbox Club, it is argued that the development of a logic model is a key area of development if this programme is set to achieve the aims it has set out. A proposed model is outlined in Figure 1. Fig. 1 Proposed logic model 


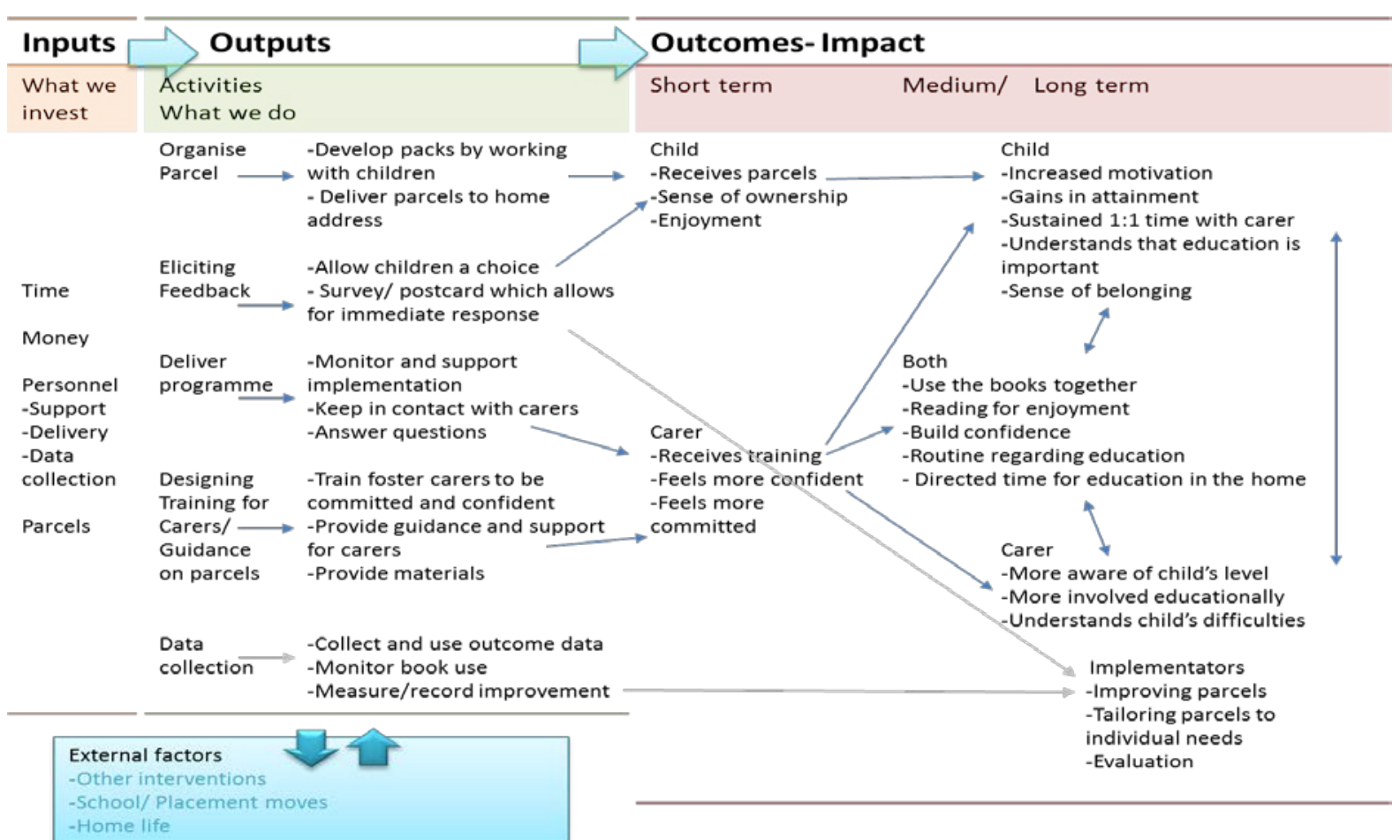

The development of a logic model to underpin and inform the future delivery of the Letterbox Club is important for a number of reasons. First, whilst at its core the Letterbox Club is a book gifting scheme (that is a gift, freely given with no expectations attached) there has been an increasing focus on its outcomes and effectiveness - that is does it improve the literacy and numeracy skills of children in foster care. A logic model that maps the inputs, outputs and outcomes helps ensures clarity around programme delivery (Durlak, 1998; Durlak \& DuPre, 2008; Duerden \& Witt, 2012). Second, a logic model can capture and define the dynamics in the foster carer/child relationship (reflective of Vygotsky, ZPD and scaffolding) that might enhance the literacy and number skills of foster children. Third, the logic model also delineates the component parts of child choice 
(reflective of the concept of the evolving capacities of the child) and the impact of child choice.

In terms of the delivery of the Letterbox Club going forward there are a number of implications. In relation to the foster children and their evolving capacities, there is a wealth of evidence which highlights that learning to read and becoming a fluent reader requires effort and determination (Birch, 2014) and that 'the pursuit of knowledge [will not continue] unless the reader realises some personal gratification or internal reward from this engagement' (Alexander and Jetton, 2000, p.296). The logic model could draw attention to small changes that could be made to the Letterbox Club to support children's choice and participation. The packs, for example, could contain a pre-paid postcard that asks children to review/ rate the books in order to influence future packs for other children and help the child, as recipient, feel more involved. More substantive changes to delivery might also help. As indicated earlier, our research highlighted that children now read books in a range of formats rather than just hard copy. By engaging with children's increasing thirst for new technology, programme creators and funders could give children a device and a gift card which would allow them to source their preferred reading material and read it electronically.

Building on the theme of children's involvement and participation, their lack of choice was something which nearly all those children included in the study felt should be changed. In particular, they wanted books which were more closely aligned with their interests and ability and which they could 
choose themselves. The development of a logic model, that allows children to choose what they read has been deemed important and so by including an 'order form' with each parcel for example, children would be able to choose what they read from a pre-selected list, an important aspect of the reading process which would also allow them to feel a greater sense of ownership towards the books. Furthermore, children have indicated that they would like to have more information about why, how, by what means Letterbox parcels arrive at their home. The role of the carer in relation to this issue may need to be more clearly defined.

Building on the point about foster carer engagement, many of the carers involved were enthusiastic and competent, however lacked the knowledge about what to do and when to do it. The development of a logic model could delineate component parts of the foster carer role building on recent related research findings regarding individual tutoring (Flynn, Marquis, Paquet, Peeke, \& Aubry, 2012) which have shown that, with training and guidance to carers/volunteers, the delivery of a regular tutoring programme over a number of weeks for a set period of time, supports children to make gains in reading in a relatively short space of time. Similarly, paired reading is an approach which has gleaned positive results for this group of children (Osborne, Alfano, \& Winn, 2010; Tordön, Vinnerljung, \& Axelsson, 2014) More generally carers could be asked to record what is read, when it is read, with whom and how long. Shared with the child involved, these records may encourage them to see the importance of reading regularly. In addition, reading records allow for child 
focused evaluation of the book choices and knowledge building around reading levels. Carers could also be asked to read an information leaflet giving tips on how to read with children and why it is important.

\section{Concluding thoughts}

By undertaking qualitative research in the form of a process evaluation this article has explored more about how the Letterbox Club scheme works in practice and reasons why it is assumed it will work. It is argued that in designing interventions, even those paved with good intentions, that are popular and well received, such as the Letterbox Club, it is important, in determining efficacy, that programmes are underpinned by a clear theory of change and that they are accompanied by a clearly delineated logic model that provides a map regarding the core components of the programme and their fit in terms of achieving the desired outcomes. It is only through adopting these rigorous processes, and accepting the time and financial commitment that goes with their development, that the social work profession can truly begin to accrue a strong evidence regarding effective interventions that genuinely improve the outcomes for this vulnerable group of children and young people. 
References

Alexander, P. A., \& Jetton, T. L. (2000). Learning from text: a multidimensional and developmental perspective. Handbook of reading research, 3, 285-310.

Bellini, S., Henry, D. and Pratt, C. (2011) 'From intuition to data: Using Logic Models to measure professional development outcomes for educators working with students on the Autism Spectrum', Teacher Education and Special Education: The Journal of the Teacher Education Division of the Council for Exceptional Children, 34 (1), pp. 37- 51.

Bennett, N., \& O'Donohue, W. (2014). The Construct of Grooming in Child Sexual Abuse: Conceptual and Measurement Issues. Journal of child sexual abuse, 23(8), 957-976.

Bickman, L. (1987) 'The functions of programme theory', In L. Bickman (Ed.) Using programme theory in evaluation. New directions for programme evaluation, no. 33. San Francisco: Jossey-Bass.

Birch, B. M. (2014). English L2 reading: Getting to the bottom. London: Routledge.

Braun, V., \& Clarke, V. (2006). Using thematic analysis in psychology. Qualitative Research in Psychology, 3(2), 77-101.

Bucher, J. A. (2010). Using the logic model for planning and evaluation: examples for 
new users. Home Health Care Management \& Practice, 22(5), 325-333.

Chall, J. S. (1983). Learning to read: The great debate. NY: McGraw-Hill Companies, Inc.

Chen, H. T. (1990) Theory-Driven Evaluations, Newbury Park: Sage.

Chen, H. T. (2005) Practical Programme Evaluation, Thousand Oaks: Sage.

Cheung, C., Lwin, K., \& Jenkins, J. M. (2012). Helping youth in care succeed: Influence of caregiver involvement on academic achievement. Children and Youth Services Review, 34(6), 1092-1100.

Clark, C., \& Phythian-Sence, C. (2008). Interesting choice: The (relative) importance of choice and interest in reader engagement. London: National Literacy Trust.

Dixon, J., Biehal, N., Green, J., Sinclair, I., Kay, C., \& Parry, E. (2014). Trials and tribulations: challenges and prospects for randomised controlled trials of social work with children. British Journal of Social Work, 44, 1563- 1581

Durlak, J. A. (1998). Why program implementation is important. Journal of Prevention \& Intervention in the community, 17(2), 5-18.

Duerden, M. D., \& Witt, P. A. (2012). Assessing program implementation: What it is, why it's important, and how to do it. Journal of Extension, 50(1), 1-8. 
Durlak, J. A., \& DuPre, E. P. (2008). Implementation matters: A review of research on the influence of implementation on program outcomes and the factors affecting implementation. American journal of community psychology, 41(3-4), 327-350.

Dwyer, J. and Makin, S. (1997) 'Using a program logic model that focuses on performance measurement to develop a program', Canadian Journal of Public Health, 88 (6), pp.421-425.

Dymoke, S. and Griffiths, R. (2010) The Letterbox Club: the impact on looked-after children and their carers of a national project aimed at raising achievements in literacy for children aged 7 to 11 in foster care. Journal of Research in Special Educational Needs, 10(1), 52-60.

Flynn, R. J., Marquis, R. A., Paquet, M. P., Peeke, L. M., \& Aubry, T. D. (2012). Effects of individual direct-instruction tutoring on foster children's academic skills: A randomized trial. Children and Youth Services Review, 34(6), 1183-1189.

Griffiths, Comber and Dymoke (2010) The Letterbox Club, 2007 to 2009: final evaluation report. London, Booktrust.

Griffiths, R. (2012) The Letterbox Club: an account of a postal club to raise the achievement of children aged 7 to 13 in foster care. Children and Youth Services Review, 34(6), 1101-1106. 
Guthrie, J. T., \& Davis, M. H. (2003). Motivating struggling readers in middle school through an engagement model of classroom practice. Reading \&Writing Quarterly, 19(1), 59-85.

Hancock, A., \& Leslie, M. (2014). Letterbox Club Scotland: Report to Booktrust. Edinburgh: Moray House School of Education.

Handley, L. (2013). Independent reading book choices of fourth grade students (Doctoral dissertation, California State University, Sacramento).

Hedin, L., Höjer, I., \& Brunnberg, E. (2011). Why one goes to school: What school means to young people entering foster care. Child \& Family Social Work, 16(1), 4351.

Hens, J., Kriz, W. C. and Wolfe, J. (2009) 'Putting theory-oriented evaluation into practice. A logic model approach for evaluating SIMGAME', Simulation and Gaming, 40 (1), pp. 110-133.

Holloway,D., Green, L. and Livingstone, S. (2013). Zero to eight. Young children and their internet use. LSE, London: EU Kids Online.

McCombs, J. S., Augustine, C. H., Schwartz, H. L., Bodilly, S. J., Mclnnis, B., Lichter, D. S., Cross, A. B. (2011). Making summer count. How summer programs can boost children's learning. Santa Monica, CA: The RAND Corporation. Retrieved from 
http://www.rand.org/content/dam/rand/pubs/monographs/2011/RAND MG1120.pdf

McKenna, M. C., \& Kear, D. J. (1990). Measuring attitude toward reading: a new tool for teachers. The Reading Teacher, 43(9), 626-639.

Mezey, G., Robinson, F., Campbell, R., Gillard, S., Macdonald, G., Meyer, D., Bonell, C., \& White, S. (2015). Challenges to undertaking randomised trials with looked after children in social care settings. Trials, 16(1), 1.

Millar, A., Simeone, R. S., \& Carnevale, J. T. (2001). Logic models: a systems tool for performance management. Evaluation and Program Planning, 24(1), 73-81.

Mooney, J., Winter, K., \& Connolly, P. (2016). Effects of a book gifting programme on literacy outcomes for foster children: A randomised controlled trial evaluation of the Letterbox Club in Northern Ireland. Children and Youth Services Review, 65, 1-8.

Moore, G.F., Audrey, S., Barker, M., Bond, L., Bonell, C., Hardeman, W., Moore, L., O'Cathain, A., Tinati, T., Wight, D., \& Baird, J. (2015). Process evaluation of complex interventions: medical research council guidance. British Medical Journal, 350, doi: http://dx.doi.org/10.1136/bmj.h1258 (Published 19 March 2015).

Neale, M. D. (1989). Analysis of reading ability, revised British edition (British adaptation and standardisation by Una Christophers and Chris Whetton). United Kingdom: NFER-Nelson, Windsor. 
Neale, M. D. (1997). Neale analysis of reading ability - Revised. Windsor: NFER Nelson.

Oakley, A., Strange, V., Bonell, C., Allen, E., \& Stephenson, J. (2006). Process evaluation in randomised controlled trials of complex interventions. British Medical Journal, 332(7538), 413-416.

Osborne, C., Alfano, J., \& Winn, T. (2010). Paired reading as a literacy intervention for foster children. Adoption \& Fostering, 34(4), 17-26.

Page, M., Parker, S. and Renger, R. (2009) 'How using a logic model refined our programme to ensure success', Health Promotion and Practice, 1 (10), pp.76-82.

Petrosino, A. (2000) 'Whether and why? The potential benefits of including programme theory evaluation in meta-analysis', New Directions for Evaluation, 87, pp.59-69.

Picton, I. (2014). The impact of eBooks on the reading motivation and reading skills of children and young people: a rapid literature review. London: National Literacy Trust.

Rogers, P. J., Petrosino, A., Huebner, T. A. and Hacsi, T. A. (2000) 'Programme theory evaluation: Practice, promise, and problems', New Directions for Evaluation, 87, pp. 5-13. 
Ryan, R. M., \& Deci, E. L. (2000). Intrinsic and extrinsic motivations: Classic definitions and new directions. Contemporary educational psychology, 25(1), 54-67.

Thyer, B. A. (2015). A bibliography of randomized controlled experiments in social work (1949-2013) Solvitur Ambulando. Research on Social Work Practice, 25(7), 753-793.

Tordön, R., Vinnerljung, B., \& Axelsson, U. (2014). Improving foster children's school performance: a replication of the Helsingborg study. Adoption \& Fostering, 38(1), 3748.

United Nations. (1989). United nations convention on the rights of the child. Geneva: United Nations.

Vygotsky, L. S. (1978). Mind in society: the development of higher mental process. Cambridge, MA: Harvard University. 